\title{
A Comparative Analysis of Chinese and English Animal Idioms from Culture Perspective
}

\author{
Shuangshuang Lyu \\ Donghai Sci-tech College of Zhejiang Ocean University, China \\ Zhouyan Li \\ Donghai Sci-tech College of Zhejiang Ocean University, China
}

\begin{abstract}
Idioms are the crystallization of human wisdom and the essences of language. Animal idioms, which can reflect people's feelings or explain complicated phenomena and rules with vivid and expressive animal images, contain rich and unique cultural connotations. This paper studies a comparative analysis of English and Chinese animal idioms from perspective of culture, aiming to make people know the cultural differences, improve their intercultural awareness and use animal idioms accurately, to promote intercultural communication more smoothly and properly.
\end{abstract}

Index Terms —English and Chinese animal idioms, cultural connotation, cultural differences, cultural influence

\section{INTRODUCTION}

Idioms are pervasive in a language, reflecting its culture even more vividly and deeply than all other kinds of words. Animal idioms vary from their literal meaning, not only reflecting people's different opinions and attitudes towards animals, but also transmitting different cultural connotations profoundly and intensively. Therefore, the study of comparing the similarities and differences of English and Chinese animal idioms will help both English and Chinese learner to have a better understanding the two cultures as well as use animal idioms more accurately and properly in intercultural communication.

\section{A. Definition and Classification of Animal Idiom}

Webster's new World College Dictionary states that idiom is to be a phrase, structure, or expression. It is regarded as a unit of practice in a given language, with a particular structure, or meaning, other than the addition of the literal meanings of words.

In generally, Chinese idioms can be roughly divided into: proverbs(浐语), allusions(典故), chengyu(成语), xiehouyu(歇后语), slang(俚语), idiomatic expressions(惯用语), colloquial sayings(俗语), couplets(成对词) and so on. (Guo, 2016, p.129) Chengyu is one of the most familiar forms in Chinese idioms.

As for English idioms, in a broad sense, they have a particular structure and meaning, including set phrases, proverbial sayings and a lot of slang expressions. In modern English, idioms refer to the habitual expression of a certain language, the special language of a certain country or nationality, the special dialect of a particular region, society or class, and the language style of famous works.

From the definitions of idioms, as a specialized form of language, differing from other phrases combined with simple words, idioms cannot be translated word by word without knowing their culture backgrounds.

As an important branch of idioms, animal idiom is also a fixed phrase cannot be translated word by word because of context and cultural connotation in it as well.

From the wide classification, animal idiom also contains Chengyu, proverbs, common sayings and so on.

From the narrow classification, animals can be divided into fish, reptiles, birds, amphibians, mammals and invertebrate animals. Thus, animal idioms are the same, we can classify them into idioms with animals living on land such as idiom “to rain cats and dogs” (倾盆大雨); animals living in the sea like “ fish out of water”(局促不安); idioms with insects like “ to have ants in one's pants” (急于行动); idioms with poultry like “cock of the walk”(称王称霸的人). (Chen, 1998, p.79)

\section{B. Features of Animal Idioms}

Both English and Chinese languages contain lots of animal idioms but have their own features.

Zhao Yan (2017) thinks that animal idioms have four features: universality, immobility, integrality, rhetoric. Universality means English idioms exist everywhere and the origin of animal idioms also depend on the geography environment. Immobility means the words in animal idioms cannot increase or decrease; they are set phrases. Integrality means animal idioms have a unique and complete meaning. Rhetoric means people make animals figurative in order to express people's minds. (p.103)

English idioms can be a fixed phrase or a sentence, but many Chinese idioms are composed of four words such as 
“狗急跳墙”, three words like “落汤鸡” and six words like “放长线钓大鱼”. In addition, Chinese animal idioms are often used in writing, but English animal idioms are commonly used in speaking.

\section{ANimAL IDIOMS AND CUlture}

As an important part of language, idiom is the core and essence of language. Meanwhile, as an essential part of idioms, animal idioms greatly show cultural connotation of a nation.

\section{A. The Relationship of Language and Culture}

Culture can be divided into material culture and spiritual culture. Therefore, culture is the deposit of people's knowledge, experience, beliefs, values, actions, attitudes, and something got by a group of people or individual person through working. (Davis, 2001, p.158)

"Language is a system of arbitrary vocal symbols used for human communication." (Wardhaugh, 2009, p.212)

"Language is the cornerstone of culture, Language and culture influence and interact with each other. As a tool of cultural transmission, Language has a great restriction on the spread of culture and is the strength for the survival of culture" (Li, 2016, p. 92)

Therefore, language and culture are inseparable. Language formation of a nation is influenced by many cultural factors including traditions, people's thinking, social psychology, customs, values and so on. Meanwhile, language affects the formation of human thinking and cultural communication. So different languages contain their own cultural connotations.

\section{B. The Relationship between Animal Idioms and Culture}

Language is the epitome of the culture, and culture is one of the most powerful factor influence the language. "Using animals as metaphors to convey emotions become a language habit of English and Chinese. The semantic understanding of idioms should consider both conceptual meaning and pragmatic meaning." (Liu, 2017, p.125) Therefore, animal idioms are also influenced by culture, and inseparable from culture as well.

English and Chinese animal idioms have their own national cultural colors. It is difficult to penetrate all the elements contained in idioms from the superficial meaning to the deep connotation and cultural characteristics. (Zhang, 2014, p. 33) We should pay attention to the expression of their language and their cultural meaning.

\section{COMPARISOn BetweEn ENGLiSh AND Chinese ANimal IDIOMS}

Animals are closely connected with human life, and are endowed with human characteristics. Animal idioms can express oneself more vividly and concisely. Different animal idioms have different meanings, but the same animal idioms also have different meanings such as dog, dragon, snake and so on.

\section{A. The Same Animal with Same Meaning}

\section{Wolf \& 狼}

"Wolf" is always regarded as destruction, danger and even evil. There are some differences between Chinese and western cultures in the perception of wolves, but the semantic meaning of destruction exists in both cultures, such as:

a. cry wolf (虚张声势)

b. keep the wolf from the door（勉强度日）

c. a wolf cub with a savage heart- -have a wolfish nature（狼子野心）

d. figuratively, cruel and brutal (狼心狗肺)

e. It is a foolish sheep that makes the wolf his confessor. (䖭羊才向狼忓悔)

f. a wolf in sheep's clothing（披着羊皮的狼）

\section{Bee \& 蜜蜂}

In contrast to the wolf, bee is the representative of diligence in Chinese and English culture. So, there are many idioms about bees as compliments, such as,

a. as busy as a bee (像蜜蜂一样奔忙)

b. bee's knees（出类拔萃)

Meanwhile, in Chinese history, there are also many poems which regard bee as a representative of assiduous:

c. The bees come again; it's so pity that they are busy all day. (墙外蜜蜂又来，可怜终日太忙生)

d. After gathering hundreds of flowers into honey, for whom hard work for whom sweet. (采得百花成蜜后, 为谁辛 苦为谁甜)

\section{Pig \& 猪}

Pig is regarded as lazy and dirty image, and there are more expression about pig such as hog, swine and so on. Thus, pig in idioms is to describe someone is greedy and lazy or someplace is very dirty and mess.

a. pig it (过着和猪一样的生活)

b. pig out (大吃大喝) 
c. as dirty and g reedy as a pig(又脏又悗)

d. In a pig's eye! (胡扯)

The idioms with pig are also to describe a group of people or individual person with bad morals such as:

e. worse than pigs or dogs (猪狗不如)

f. pigs love that lie together (臭味相投)

\section{Snake \& 蛇}

Snake culture has a long history that could be traced back to ancient time in Chinese culture, and to the period of the Bible in English culture. Snakes are known for their cold blood and not close to humans, so there are a lot of animal idioms in Chinese and English about snakes with negative meanings, and some implicate a group of evil people and things:
a. snake in the bosom (忘恩负义的人)
b. to nurse a snake in one's bosom (护恶养奸)
c. deal with someone courteously but without sincerity (虚与委蛇)
d. have a heart as malicious as snakes and scorpions (蛇蝎心肠)
e. a man whose heart is not content is like a snake which tries to swallow an elephant(人心不足蛇吞象)

\section{B. The Same Animal with Different Meanings}

Different nations live in different cultural environments and with different religious beliefs and histories which influence people's association of cultural meanings of idioms. (Liu, 2017, p.127) Due to the differences between Chinese and English culture, the same animal in idioms have different meanings.

\section{Dog \&狗}

In China, most of people keep dogs for security guard especially in rural area and more and more people keep them as pets. In ancient China, people thought that dogs like to bark, and their bark indicates bad omen. So, they always use dog's blood to expel ominous. Besides, the idioms are usually used to satirize or even insult people, such as:

a. every dog is valiant at his own door (狗是百步王, 只在门前凶)

b. be on the sly (偷鸡摸狗)

c. like a dog counting on its master's backing (狗仗人势)

But in English, dogs are the best friend of human, there is one saying about dog and god — spelling dog from right to left is God. So, most English idioms with dogs are positive, and the image of a dog is often used to describe human behavior such as:
d. hot dog (真开心啊)
e. you are a lucky dog (你是一个幸运儿)
f. love me, then love my dog (爱屋及乌)
g. every dog has his day (每个人都有他得意的时候)

\section{Dragon \& 龙}

Dragon has a history of more than 5,000 years in China. For people, the dragon is a special existence, which is regarded as the embodiment of god and also a symbol of power. Emperor was called the real dragon and the son of heaven in ancient China. And now dragon is treated as an auspicious and peaceful symbol in our daily life, such as,

a. dragon and phoenix present auspiciousness (龙凤呈祥)

b. the spirit of people just like dragons and horses (龙马精神)

c. dragons rising and tigers leaping -- a scene of bustling activity (龙腾虎跃)

d. full of life and energy(生龙活虎)

However, as for English people, dragon symbolizes evil. People often use "Dragon" to describe people who are fierce. In addition, in Bible, people call the demon who fights against god "the great dragon". So, in English idioms, dragon is used in a negative way.

e. sow dragon's teeth (挑起纠纷)

f. a dragon of woman（凶悍的女人）

\section{Bat \& 蝙蝠}

In China, bat symbolizes auspiciousness, happiness and longevity, because it sounds like "fu" in Chinese, the pronounce of “蝠” and “福” are the same, so it is associated with good luck, auspiciousness and happiness. Many folk paper-cut patterns use bats to represent lucky, for example, cutting paper with bats and peach (indicts 长寿 longevity) together metaphorically means enjoying both happiness and longevity (福寿双全). Bats and deer (the same sound with 禄 opportunities) composition means having both fame and wealth(福禄双全). Bats and fish(the same sound with 余 abundance) composition contain the meaning of "richer and luckier"(富贵有余).

However, bats in western countries are seen as the embodiment of evil. And in European folk culture, people often associated bats with evil and the dark side. Look at following English animal idioms:

a. crazy as a bat (发疯) 
b. have bats in the belfry (胡说八道)

c. as blind as a bat (有眼无珠)

\section{Magpie \&喜鹊}

Magpie in China is a representative of good luck, because people think that its voice would bring good news. Besides, it is an auspicious bird, here is a fairy tale about Niu lang and Zhi Nv, they meet on the Milky Way on July 7th every year and magpies gather to bridge their paths.

a. The magpie smiles and the turtledove dances. (鹊笑鸠舞)

b. Magpies chirp, good things come to my house. (喜鹊叫喳喳, 好事到我家)

c. Magpies chirp on the branch, it's sunny. (喜鹊枝头叫, 出门晴天报)

But in Scotland, the magpie is considered as a death omen: in England, magpies are often spat upon to ward off bad luck.

d. Magpies that chatted, no omen so black. (鹊噪为最坏的兆头)

\section{REASONS FOR THE DiFFERENCES BETWEEN ENGLISH AND CHINESE ANIMAL IDIOMS}

Comparing the English and Chinese animal idioms, we know the same animal might have the same meaning, but also could be different due to the culture differences, which will lead to misunderstanding and the failure of communication. So, it's essential to find the reasons for the differences between English and Chinese animal idioms.

\section{A. The Influence of Geographical Environment}

Geographical environment plays an important role in one nation's culture. Different geographical features breed different idioms, different idioms carry different cultures.

The territory of the United Kingdom includes England, Scotland, Wales and Northern Ireland. Britain is on an island, surrounded by the sea, and contains abundant fishing resources. There is no doubt that water resource is vital to them, and fish makes a great impact on people's daily life, so many animal idioms related to water and fish in English such as “a fish out of water” (如鱼得水), “fish in troubled waters” (浑水摸鱼), a queer fish (性格古怪的人), a cold fish (冷 酷无情的人), not the only fish in the sea (多的很), only a small fish (小人物). In addition, animal husbandry is also well developed in Britain, so there are a lot of animal idioms related to sheep, wool is the chief income for shepherds, so idiom such as "lose one' s wool" (发怒) is to describe someone who is very angry.

However, China lies on the Asian continent, people cannot live without soil. In ancient time, with its advanced agricultural technology, China became a great agricultural country. Therefore, there are a lot of people live in rural areas who depend on farming, so a large proportion of idioms related with cattle, for instance, “牛脾气”, “牛肥马壮”, “牛 头不对马嘴” and “对牛弹琴”. And there are many animal idioms from agriculture such as “it is good horse that never stumbles" (好马不失蹄), “fuel is not sold in a forest, nor fish on a lake" (林中不卖柴, 湖上不卖鱼), “old wood is best to burn, old horse to ride" (好柴好烧, 好马好骑).

Compared the origin of English idioms and Chinese idioms from their own living circumstances, it can be seen that the geographical environment has a great effect on idioms. The geographical environment of a country directly affects the natural resources of a country.

\section{B. The Influence of Historical Development}

In the development of human history, with the change of society, the migration of nations, the conquest and assimilation of nations and the wars between nations, the foreign national cultures have an impact on the English language. History plays an important role in the formation of idioms, and many idioms come from historical events.

The historical development of the English-speaking countries, especially Britain has greatly influenced the English language. Britain has been invaded by many natives throughout its history such as the ancient Romans, the Greeks. Here is an idiom "rain cats and dogs" (倾盆大雨), it means rain heavily, coming from a history event. It is because of the invasion of Scandinavians that directly affects the formation of these English animal idioms. In ancient times, Norsemen's god was Odin, they saw dog as wind, cat as rain. So, cats and dogs together symbolize "storm". Besides, it's also influenced by history stories. In Western, there are a lot of stories and sentences from Bible, for example, here is a sentence: Do not give dogs what is holy to dogs- they will only turn and attack you. We can translate it into Chinese like “狗咬吕洞宾, 不识好人心”.

While in China, idioms are also influenced by history and history stories. In Chinese history development, there is a person of great significance to China called Mao Zedong, he said that All imperialism and reactionaries are paper tigers (一切帝国主义和反动派都是纸老虎). Tigers are ferocious in my mind, but paper tiger is fake, which motivated people's confidence and encouraged them not be afraid at that hard time. Nowadays, people used to compare difficulties and setbacks with paper tiger, because people will eventually be able to defeat them with persistent efforts. And there are also many idioms from Chinese history stories like “亡羊补牢”（mend the fold after the sheep have been stolen）， the purpose of this story is to tell people to remedy the mistakes in time. 


\section{The Influence of Religions and Beliefs}

Religious belief is an essential part of social culture and the embodiment of people's spiritual life. It has an important significance in social life, and its influence is obviously reflected in language. (Zhao, 2014, p.33)

Religion is not only considered as a certain ideological belief, but also serves as a kind of universal cultural phenomenon containing deep-provoking contents. After a long history of evolution and development, religion has created a rich and colorful religious culture. They have not only made outstanding contributions to social science, literature, art, ethics and many other cultural fields, but also had a great and far-reaching impact on the development of Chinese and English idioms. (Zhao, 2008, p.145)

In western countries, God is the ruler, the supreme existence, and god is unique. The religion of Britain is New Christianity spread by the Anglican church. Bible is the classic of Christianity, which contains allusions, metaphors and proverbs, many of them become well-known idioms. In addition, many animal idioms come from the Bible, such as “lion on the way” (拦路虎); a land of milk and honey(丰饶的地方), cast pearls before swine(对牛弹琴).

On the contrary, Chinese people believe Confucianism, Buddhism, Taoism and so on. Confucianism take the five principles "integrity, wisdom, humanity, courtesy and honesty" as the core. Buddhism is spread by India monks in China. After a long period of propagation and development, Buddhism with Chinese characteristics came into being. It takes goodness as men's essential believes all physical existence is vanity. Therefore, there are many idioms related to Buddhism such as “a beast in human face” (人面兽心); “devils in animal forms” (牛头马面). Buddhism emphasizes kindness and mercy; the believers always think saving one's life from death is better than building a seven-storied pagoda and they also believe people has a past life and next life, what you have done in your life will influence the destiny of your next life. So, they account that killing animals even ants should be banned. Besides, Taoism also plays an important role in Chinese culture, valuing the balance of Yin and Yang, natural and simple life. There are some old sayings from Taoism,“一人得道，鸡犬升天”(one person get the moral, towards each other to heaven), “狗咬吕洞宾， 不识好人心”( mistake a good man for a bad one).

\section{CONCLUSION}

Comparing English and Chinese animal idioms, it is clear that due to different living circumstances, religions and histories, animal idioms with different cultural connotation will deeply influence intercultural communication.

Knowing the animal idioms with their cultural characteristics, we can have a good command of the essence of idioms, and better understand the same or different meanings behind each animal idiom, helping us use the animal idioms correctly, and carry out intercultural communication more properly and effectively.

\section{REFERENCES}

[1] Chen Guangwu. (1998). Classification of English Animals Idioms. Journal of Linling Teachers College, 3, 79-82.

[2] Guo Xiaoyan. (2016). The Cultural Origin and Corresponding Translation of English and Chinese Idioms. Overseas English, 17,169-170.

[3] Li Hua. (2016). Differences between Chinese and Western Languages and Cultures from English and Chinese idioms. Journal of Jinan Vocational College, 5, 92-93.

[4] Linell Davis. (2011). Cross-Cultural Communication in Action. Beijing: Foreign Language Teaching and Research Press, 158.

[5] Liu Quanhua. (2017). Comparative Analysis of English and Chinese Animal Idioms. Social Sciences Review, 32(04), 125-130.

[6] Ronald Wardhaugh. (2009). An Introduction to Sociolinguistics. Shanghai: Fudan University Press.

[7] Zhao Dongxia. (2014). On the Cultural Differences between China and the West from the Perspective of English and Chinese Idioms. Journal of Mudanjiang College of Education, 9, 32-33.

[8] Zhao Yan. (2017). The characteristics and translation strategies of English Animal Idioms. An Hui Literature, 5, $103-106$.

[9] Zhang Pan. (2014). Cultural differences and Translation Methods in English and Chinese Idioms. English Square (Academic Research), 11, 32-33.

[10] Zhao Zhilan. (2008). The influence of religious culture on English and Chinese idioms. Journal of Social Science of JIAMUSI University, 1, 145-146.

Shuangshuang Lyu, was born in Shengzhou, Shaoxing, China in 1997. She is studying for bachelor degree in English major in Donghai Sci-tech college of Zhejiang Ocean University, China.

Zhouyan Li, was born in Zhoushan, China in 1982. She received Master degree in linguistics from Zhejiang Normal University in 2008 and in advanced education management from Ningbo University, China in 2012.

She is currently a lecturer in Donghai Sci-tech college of Zhejiang Ocean University, China. Her research interest is in the field of inter-culture communication. She is the supervisor of the first author, and is the corresponding author. 